\title{
Impeachment of Witnesses by Prior Convictions Pending Appeal
}

Almost all English-speaking jurisdictions permit the introduction of a witness's prior criminal convictions for the purpose of attacking his credibility. ${ }^{1}$ Rule 609 of the Federal Rules of Evidence sets forth the conditions for the admissibility of such evidence. ${ }^{2}$ Rule 609 (a) provides as a general rule that evidence of a witness's convictions for crimes of a serious nature and certain crimes particularly relevant to credibility, such as perjury, are admissible for impeachment purposes. ${ }^{3}$ While American jurisdictions were nearly unanimous in their practice of admitting evidence of prior convictions for impeachment purposes at the time of enactment of the Federal Rules of Evidence, there was disagreement within both state and federal jurisdictions regarding a collateral issue-the significance of a witness's pending appeal from a conviction. The Federal Rules, following the majority of state and federal courts, resolved the issue for the federal courts in favor of admissibility. Rule 609(e) provides that pendency of an appeal does not preclude use of the conviction as impeachment evidence. ${ }^{4}$ The inclusion of this provision in the Federal Rules was apparently not controversial, and the legislative history of rule 609 provides little insight into the rationale for the admissibility of convictions pending appeal.

Although the application of rule 609(e) presents few problems of interpretation, the need for an explanation of the rule arises for at least two reasons. First, it is unclear whether Congress's adoption of rule $609(\mathrm{e})$ constituted a decision that the possibility of subse-

' 3A J. Wigmore, Evidence $\S \S 980,986$ (J. Chadbourn rev. 1970). But see Mont. R. Evid. 609 ("For the purpose of attacking the credibility of a witness, evidence that he has been convicted of a crime is not admissible.").

2 In addition to the provisions of rule 609 discussed in this comment, the rule also covers admissibility of convictions under various special circumstances. See Fed. R. Evid. 609(b) (convictions remote in time); FED. R. EvD. 609(c) (pardons, annulments, and certificates of rehabilitation); FED. R. Evid. 609(d) (juvenile adjudications).

${ }^{3}$ (a) General Rule. For the purpose of attacking the credibility of a witness, evidence that he has been convicted of a crime shall be admitted ... but only if the crime (1) was punishable by death or imprisonment in excess of one year under the law under which he was convicted, and the court determines that the probative value of admitting this evidence outweighs its prejudicial effect to the defendant, or (2) involved dishonesty or false statement, regardless of the punishment.

Fed. R. Evid. 609(a).

+ "(e) Pendency of appeal. The pendency of an appeal therefrom does not render evidence of a conviction inadmissible. Evidence of the pendency of an appeal is admissible." FED. R. Evid. 609(e). 
quent reversal engenders no significant problems. Neither the language nor the legislative history makes clear what relief, if any, should be granted when a witness's conviction is reversed on appeal. Second, the lack of an explanation of rule 609(e) complicates and limits its use as a model rule. The 1974 edition of the Uniform Rules of Evidence ${ }^{5}$ employs the language of the Federal Rules, with few changes, and several states have enacted codes of evidence that follow the model of the Federal Rules. ${ }^{6}$ Yet, just as states disagreed in the past over the effect of a pending appeal, some states that have generally followed the model of the Federal Rules have chosen to exclude rule $609(\mathrm{e}) .^{7}$ Reluctance of some jurisdictions to adopt the rule suggests that there may be something in the logic of impeachment under the general theory of rule 609 that militates against the admissibility of convictions pending appeal.

This comment attempts to set forth a rationale for rule 609(e) that answers the questions on which Congress was silent. To this end, after exploring the rationales of the federal and state cases that constitute the "legislative history" of the rule, the comment examines the use of prior criminal acts to impeach witnesses and the role of a conviction in proving such acts. Upon this framework, the comment then explicates the justification for admitting convictions as impeaching evidence notwithstanding a pending appeal and considers the courses open to the courts should such a conviction ultimately be reversed on appeal.

\section{Impeachment by Prior Convictions Pending Appeal: In Search of a Legislative Rationale}

Rule 609(a) permits an attack on the credibility of a witness with "evidence that he has been convicted of a crime."8 The role of

5 13 U.L.A. 197 (1975).

- See generally, 3 J. Weinstein \& M. Berger, Weinstein's Evidence ๆ 609[08] (Supp. 1978) [hereinafter cited as WeInSTEIn's Evidence.] Two states have adopted rule 609 by decisions of the states' supreme courts. People v. Montgomery, 47 III. 2d 510, 268 N.E.2d 695 (1971); State v. Morgan, 541 S.W.2d 385 (Tenn. 1976).

7 Me. R. Evid. 609; Neb. Evid. R. 609(5).

* FED. R. Evid. 609(a). Rule 609(a) gives the trial court no authority to exclude convictions for crimes involving "dishonesty or false statement." FED. R. EvID. 609(a)(2). The rule allows the court to admit convictions for other crimes only if it "determines that the probative value of admitting this evidence outweighs its prejudicial effect to the defendant." FED. $R$. Evid. 609(a)(1). See United States v. Mahone, 537 F.2d 922 (7th Cir.) (factors relevant to the weighing of probative value and risk of prejudice), cert. denied, 429 U.S. 1025 (1976). Note that rule $609(\mathrm{a})(1)$ allows the court to consider the risk of prejudice only as it affects the defendant. "Rule $609(\mathrm{a})(1)$ reflects a deliberate choice to regulate impeachment by prior conviction only where the defendant's interests might be prejudiced by admission of evidence of past crimes, and not where a nondefendant might suffer, or where a nondefendant witness 
a prior crime in impeaching a witness's testimony is to provide circumstantial evidence of his insincerity ${ }^{9}$ from which the jury may infer that he is generally untrustworthy. From this inference of untrustworthy character, considered together with other evidence relevant to the witness's credibility, ${ }^{10}$ the jury may further infer that the witness is lying in his specific testimony. Although no empirical study has demonstrated any significant correlation between a person's prior crimes and his propensity to lie in court, ${ }^{11}$ rule 609(a)

complains of possible loss of reputation in the community." United States v. Smith, 551 F.2d 348, 359 (D.C. Cir. 1976) (footnote omitted). Cf. United States v. Jackson, 405 F. Supp. 938 (E.D.N.Y. 1975) (impeachment of prosecution witness would have prejudicial effect on defendant).

Two questions of the court's authority under rule 609(a)(1) remain unanswered. The first is whether the court may prohibit impeachment of a nondefendant witness with a prior conviction that has a prejudicial effect on the defendant. When the subject of impeachment is a criminal defendant testifying on his own behalf, a danger arises that the jury will rely on the evidence to determine not only the defendant's credibility, but also his guilt for the offense for which he is charged. See H. Kalven \& H. Zetset, The American JuRY 159-60 (1966); C. MCCoRmick, HANDBoOK of THE LAW of Evidence $\$ 43$, at 89-90 (2d ed. E. Cleary gen. ed. 1972) [hereinafter cited as HANDBOOK]. The legislative history, reflecting this concern, suggests that the court is to exercise its discretion only when the defendant himself is impeached. See H.R. REP. No. 1597, 93d Cong., 2d Sess. 9-10 (1974) ("Such evidence should only be excluded where it presents a danger of improperly influencing the outcome of the trial by persuading the trier of fact to convict the defendant on the basis of his prior criminal record.") (emphasis added). But see 3 WeINSTEIN's EvidencE, supra note 6, T 609[3a], at 78 ("balancing approach of Rule 609(a) is not limited to defendant as a witness"). Weinstein notes that in some cases a defense witness's prior crime will be held against the defendant. For example, the jury might develop bias against a defendant when it hears of the prior crimes of the defendant's relative, associate, or codefendant testifying on his behalf. Id. at 78-79.

The second unanswered question is whether rule $609(\mathrm{a})(1)$ authorizes the court to consider the risk of prejudice to parties in civil actions. The Federal Rules of Evidence apply to civil as well as criminal trials, and rule 609(a)(1) does not expressly limit the scope of the court's concern to protection of the criminal defendant. FED. R. Evid. 1101(b). The legislative history, however, makes clear that Congress considered only the prejudicial effects of prior crime evidence on criminal defendants. H.R. RBP. No. 1597, supra, at 9-10 ("Such evidence should only be excluded where it presents a danger of improperly . . . convict[ing] the defendant"). Admission of a prior conviction may have a prejudicial effect on parties to a civil suit, see Sanitary Milk Producers v. Bergjans Farm Dairy, Inc., 368 F.2d 679 (8th Cir. 1966); Chambers v. Robert, 110 Ohio App. 472, 166 N.E.2d 530 (1959), but it would be anomalous to limit the balancing of prejudice and probative value to civil defendants. In a civil case, jury prejudice is equally likely to develop against either a plaintiff or a defendant whose testimony is impeached by evidence of his prior crime.

- See Ladd, Techniques and Theory of Character Testimony, 24 Iowa L. REv. 498, 53235 (1939).

" See, e.g., FED. R. Evid. 608(a) (opinion and reputation evidence of character); FED. R. Evid. 613(b) (prior inconsistent statement of witness). See generally HaNDBOOK, supra note 8, §§ 33-50.

" Legal opinion about the strength of the correlation is divided. Compare $5 \mathrm{~J}$. Bentham, Rationale of Judicial Evidence 78-124 (London 1827); Ladd, Credibility Tests-Current Trends, 89 U. PA. L. REv. 166, $176-78$ (1940) (correlation cannot be very strong) with Gertz v. Fitchburg R.R. Co., 137 Mass. 77, 78 (1884) (Holmes, J.) and Hearings on Proposed Rules of Evidence Before the House Comm. on the Judiciary, 93d Cong., 1st Sess. 251 (1973) 
reflects the Advisory Committee's assertion that " $[t]$ here is little dissent from the general proposition that at least some crimes are relevant to credibility." 12 A conviction is a relevant piece of impeachment evidence because it is proof of the witness's guilt for a crime, from which the jury may draw these inferences. ${ }^{13}$

Rule 609(e) applies rule 609(a)'s general rule of admissibility in the specific case of a conviction pending appeal. ${ }^{14}$ The significance of an appeal is that it may raise a question about the correctness of the finding of guilt in the prior proceeding and thus bear directly on the reliability of the conviction as evidence of the witness's criminal acts. Neither the language nor the history of rule 609(e), however, gives an adequate explanation of why this reduction in reliability should not preclude the admissibility of convictions pending appeal.

The "legislative history" of rule 609(e) is very brief. In contrast to the controversy that surrounded the adoption of rule $609(\mathrm{a}),{ }^{15}$ rule 609(e) received little attention during the process of drafting the Federal Rules. ${ }^{16}$ The "legislative history" consists entirely of the brief Advisory Committee Note on the rule and the practice of the

(testimony of Friendly, J.) ("[D]o you really think if you were on a jury, you would not like to know if the witness had committed murder. I think I would like to know.").

12 FED. R. Evib. 609, Advisory Comm. Note, 56 F.R.D. 183, 270 (1973). The use of a prior conviction to impeach is an exception to the general rule barring evidence of prior crimes to prove propensity to commit a particular act. See FED. R. Evid. 404(b). Prior crime propensity evidence is part of the broader class of character evidence. Such evidence is generally inadmissible because its relatively low probative value is outweighed by the danger of undue prejudice, confusion of issues, waste of judicial resources, and surprise to a party. HANDBOoK, supra note 8, § 188; see FED. R. Evid. 403. See generally FED. R. EvID. 404, Advisory Comm. Note, 56 F.R.D. 183, 219 (1973). In the case of a criminal defendant testifying on his own behalf, the central risk is that the jury will find him guilty because of his prior criminal acts. 3 Weinstein's Evidence, supra note 6, ๆ 609[2], at 609-58. The inferences that the jury is asked to draw for impeachment purposes differ from the inference that a person who has committed a prior crime is likely to have committed the act in question. Rule 609 apparently reflects a belief that prior crime evidence is sufficiently probative of credibility to overcome the dangers that give rise to the general presumption against use of character/propensity evidence.

13 Ladd, supra note 11, at 176.

14 Fed. R. Evid. 609(e).

15 See generally, 3 Weinstern's Evidence, supra note 6, at 609-2 to 609-46.

16 The rule appeared in its final form in the first draft of the proposed rules published by the Supreme Court's Advisory Committee. 46 F.R.D. 161, 295 (1969). The Advisory Committee published two revisions of its proposed rules before submitting them to Congress. 51 F.R.D. 315 (1971); 56 F.R.D. 183 (1973); several revisions of the proposed rules were made in Congress. See generally 1 WeInstzin's Evidence, supra note 6, at vii-xii. Commentators on the proposed draft gave it only brief consideration. See Glick, Impeachment by Prior Convictions: A Critique of Rule 6-09 of the Proposed Rules of Evidence for U.S. District Courts, 6 CRIM. L. Bull. 330, 346 (1970); Krauser, The Use of Prior Convictions as Credibility Evidence: A Proposal for Pennsylvania, 46 Temple L.Q. 291, 314 (1973). There is no record of comment or debate on the rule in either house of Congress. 
state and federal courts prior to the adoption of the Federal Rules, which that Note incorporates. The Advisory Committee Note states that "the presumption of correctness which ought to attend judicial proceedings supports the position that pendency of an appeal does not preclude use of a conviction for impeachment."17 In support of this assertion, the Note cites three federal court cases. ${ }^{18}$ In the first of these, United States v. Empire Packing Co. ${ }^{19}$ the Seventh Circuit justified the rule by stating that a conviction remains valid during the period of pendency: "Unless and until the judgment of the trial court is reversed, the defendant stands convicted and may properly be questioned regarding said conviction solely for the purpose of testing credibility." ${ }^{20}$ Subsequent decisions in other federal circuits followed both the holding and stated rationale of Empire Packing, which soon became the majority position. ${ }^{21}$

The cited federal cases share with the Advisory Committee Note a paucity of analysis. The court in Empire Packing offered as its authority the position of the majority of state courts that had considered the issue. ${ }^{22}$ The state courts approached the problem by asking whether the term "conviction" in the respective state impeachment statutes ${ }^{23}$ included convictions pending appeal. Almost all the courts agreed an accusation or indictment would not suffice: a conviction is that stage of a criminal prosecution at which the witness is actually found to be guilty. ${ }^{24}$ Under one line of cases, ${ }^{25}$ a

17 Fed. R. Evid. 609(e), Advisory Comm. Note, 56 F.R.D. 183, 272 (1973).

1* The note cites United States v. Empire Packing Co., 174 F.2d 16 (7th Cir.), cert. denied, 337 U.S. 959 (1949), Bloch v. United States, 226 F.2d 185 (9th Cir.), cert. denied, 350 U.S. 948 (1955), and Newman v. United States, 331 F.2d 968 (8th Cir. 1964).

1 174 F.2d 16 (7th Cir.), cert. denied, 337 U.S. 959 (1949).

20 Id. at 20.

21 United States v. Franicevich, 471 F.2d 427 (5th Cir. 1973); United States v. Owens, 271 F.2d 425 (2d Cir. 1959), cert. denied, 365 U.S. 874 (1961); Bloch v. United States, 226 F.2d 185 (9th Cir.), cert. denied, 350 U.S. 977 (1955); see Newman v. United States, 331 F.2d 968 (8th Cir.), cert. denied, 379 U.S. 975 (1964) (reaching the same result without deciding the issue). Contra, Campbell v. United States, 176 F.2d 45 (D.C. Cir. 1949).

$22174 \mathrm{~F} .2 \mathrm{~d}$ at 20.

2 The statutory authority to admit evidence of conviction to impeach witnesses originated in enactments that removed the common-law rule disqualifying testimony of persons convicted of crimes. HANDBooK, supra note $8, \S 43$, at 84-85. The New York provision is typical: "A person who has been convicted of a crime is a competent witness; but the conviction may be proved, for the purpose of affecting the weight of his testimony, either by crossexamination, upon which he shall be required to answer any relevant question, or by the record." N.Y. Crv. Prac. Law R. § 4513 (McKinney 1963). See also N.Y. PENaL Law § 2444 (McKinney 1967) (similar statute governing criminal trials).

${ }^{24}$ See cases cited in 3A J. WIGmoRE, supra note 1 , $\$ 987$. See also HANDBooK, supra note $8, \S 43$, at n.52.

2s See, e.g., People v. Braun, 14 Cal. 2d 1, 92 P.2d 402 (1939); People v. Ward, 134 Cal. 
jury's verdict of guilty constitutes a conviction for purposes of the state's impeachment statutes. ${ }^{26}$ Other state courts, concerned that errors in the jury's verdict in the first prosecuition not harm the accused in the second trial, ${ }^{27}$ have defined "conviction" as requiring that the trial court in the prior proceeding have entered a final judgment of conviction. ${ }^{28}$ But despite this disagreement, the majority of both lines has relied on a technical distinction to hold that the filing of an appeal suspends only the enforcement of the judg-

301, 66 P. 372 (1901); State v. Johnson, 141 Wash. 324, 251 P. 589 (1926). See also Commonwealth v. Reynolds, 365 S.W.2d 853, 856 (Ky. 1963).

2 For example, one early decision, Manning v. State, 7 Okla. Crim. 367, 123 P. 1029 (1912), explained that a jury verdict satisfied the statutory requirement of a conviction because it removed the law's presumption that an accused is innocent and instead established a presumption of guilt. The court explained this shift of presumption in terms of the trustworthiness of a jury's verdict: "The law presumes that the jury was intelligent and impartial and that they would not find a man guilty upon mere suspicion or an accusation of his enemies." Id. at $370,123 \mathrm{P}$. at 1030 . The court's only concession to the possibility of jury error was that the fact of an appeal or reversal could be shown on the witness's behalf.

Although the court in Manning invoked the reliability or "trustworthiness" of a criminal jury verdict as its rationale for permitting use of convictions as impeaching evidence, it failed to consider the significance of the pending appeal in light of this rationale. Manning, like other cases equating "conviction" with a jury verdict, see note 25 supra, relies on the formal distinction between the functions in a criminal trial: the jury decides whether the accused is guilty and the court decides whether to give legal effect to a finding of guilty by entering a judgment. See People v. Wood, 134 Cal. 301, 66 P. 372 (1901). Under this view, although a guilty verdict is not necessarily sufficient proof of guilt after a trial or appellate court has set aside the verdict, $i d$. at $308-09,66 \mathrm{P}$. at 374 , a conviction is admissible during the pendency of an appeal just as it would be if the court had not yet entered a judgment based upon the jury's verdict. People v. Rogers, 112 Cal. App. 615, 297 P. 924 (1931).

${ }_{27}$ The problem is most acute when the criminal defendant takes the stand in his own behalf and is impeached with a prior conviction, since the risk is greatest in these cases that a prior conviction will prejudice a litigant. See Note, Other Crimes Evidence at Trial: Of Balancing and Other Matters, 70 YALE L.J. 763 (1961). Impeachment evidence is also admissable, however, to impeach witnesses other than the defendant in criminal trials and all witnesses in civil cases. Courts have generally limited the admissibility of convictions to impeach in these cases with the same rules they have used for impeachment of criminal defendants. See, e.g., Harbin v. Interlake S.S. Co., 470 F.2d 99, 106 (6th Cir.), cert. denied, 437 U.S. 905 (1978); Davis v. United States, 409 F.2d 453, 456 (D.C. Cir. 1969); Hackett v. Freeman \& Graves, 103 Iowa 296, 298, 72 N.W. 528, 529 (1897). But see note 8 supra.

2 See People v. Goff, 187 Colo. 57, 60, 530 P.2d 512, 513-14 (1974); Commonwealth v. Finkelstein, $191 \mathrm{~Pa}$. Super. 328, 156 A.2d 888, 892 (1959). This "final judgment" interpretation raises a problem with using a conviction during the pendency of an appeal, since the effect of an appeal is generally to suspend the judgment. FED. R. APP. P. 8; FED. R. CRIM. P. 38. Nonetheless, a majority of the states that read the impeachment statutes as requiring a final judgment have held that a conviction pending appeal retains its status as a final judgment until a higher court reverses it. Suggs v. State, 6 Md. App. 231, 236, 250 A.2d 670, 67273 (1969); Nicholson v. State, 254 So. 2d 881, 884 (Miss. 1971); Shaffer v. State, 124 Neb. 7 , 10-11, 244 N.W. 921, 923 (1932). A judgment from which an appeal is pending thus satisfies the requirement of a conviction for impeachment purposes. See Dickson v. Yates, 194 Iowa 910, 920, 188 N.W. 948, 952 (1922) (citing Hackett v. Freeman \& Graves, 103 Iowa 296, 72 N.W. 528 (1897)). 
ment, not its status as a finding of guilt. ${ }^{29}$

The difference between these two lines of state cases does little to illuminate the legislative intent of rule $609(\mathrm{e})$. Several courts-both state and federal ${ }^{30}$-following the majority rule of admitting convictions pending appeal have failed to distinguish the two approaches. And when the Seventh Circuit stated in Empire Packing that the witness "stands convicted," it gave no clear indication whether this was due to the jury's verdict or the court's entry of judgment. ${ }^{31}$ These cases represent a single approach in their reliance on rules governing final judgments of conviction for purposes other than use as impeachment evidence. ${ }^{32}$

One significant minority line of state and federal cases has held that convictions may not be admitted as impeachment evidence pending appeal. These courts have not taken the approach of determining whether the convictions satisfy a general statutory definition, ${ }^{33}$ but have responded to a special concern that the reversal of a conviction after it is used to impeach is an undesirable result. The District of Columbia Circuit first expressed this concern in a 1949 decision, Campbell $v$. United States. ${ }^{34}$ The court explained, "if the

20 Viberg v. State, 138 Ala. 100, 107, 35 So. 53, 55 (1903) ("the judgment of conviction remained in full force and effect in so far as it was an adjudication of the guilt of the defendant, for the purpose for which it was offered in evidence").

30 See cases cited in note 21 supra. See also United States v. Allen, 457 F.2d 1361, 1363 (9th Cir.), cert. denied, 409 U.S. 869 (1972).

31 174 F.2d at 20.

32 See, e.g., People v. Spears, 83 Ill. App. 2d 18, 23, 226 N.E.2d 67, 69 (1967) (citing Keenan v. McGuane, 13 Ill. 2d 520, 150 N.E.2d 168, cert. denied, 358 U.S. 828 (1968)); People v. Bey, 42 IIl. 2 d 139, 146, 246 N.E.2d 287, 291 (1969) (appeal does not suspend conviction for purposes of statute creating vacancy in public office upon conviction of incumbent); Viberg v. State, 138 Ala. 100, 106, 35 So. 53, 55 (1903) (citing Ritter v. Democratic Press Co., $68 \mathrm{Mo} .458$ (1878)) (appeal does not affect common-law rule disqualifying convicted persons as witnesses); Commonwealth v. Gorham, 99 Mass. 420, 422 (1868) (same).

"Other state courts have relied on the final-judgment interpretation of "conviction" to hold convictions pending appeal inadmissible. E.g., Foure v. Commonwealth, $214 \mathrm{Ky} .620$, 628,283 S.W. 958, 962 (1926) ("an appeal in a criminal case suspends the judgment, which does not become final until the termination of an appeal"); accord, Burford v. Commonwealth, 179 Va. 752, 765, 20 S.E.2d 509, 514 (1942); Ringer v. State, 137 Tex. Crim. 242, 246 47,129 S.W.2d 654,656 (1939). These cases generally parallel the majority-rule cases to the extent that they rely on cases regarding the suspension of convictions for purposes other than impeachment. See Adkins v. Commonwealth, 309 S.W.2d 165, 166 (Ky. 1958) (citing City of Pineville v. Collete, 294 Ky. 853, 172 S.W.2d 640 (1943)) (disqualification of public office holders); Neal v. Commonwealth, $221 \mathrm{Ky} .239$, 298 S.W. 704 (1927) (possession of intoxicating liquors by one previously convicted of same offense)). They differ from the majority cases only over the general rules governing final judgments, not the particular significance of a pending appeal for the policies underlying use of convictions to impeach.

" 176 F.2d 45 (D.C. Cir. 1949). See also Fenwick v. United States, 252 F.2d 124 (D.C. Cir. 1958); Beasley v. United States, 218 F.2d 366 (D.C. Cir. 1954), cert. denied, 349 U.S. 907 (1955). 
judgment of conviction is later reversed, the defendant has suffered, unjustly and irreparably, the prejudice, if any, caused by the disclosure of the former conviction." 35 Finding this result to be "wholly illogical and unfair," it held that a conviction was not admissible to impeach a witness during the period of pendency. ${ }^{36}$ The concern in Campbell, as well as in similarly decided state cases, ${ }^{37}$ is that the defendant might have suffered a second conviction obtained largely because the introduction of the first conviction (later reversed) discredited his testimony.

The Advisory Committee Note to rule 609(e) makes clear that the draftsmen had in mind the majority position of the federal circuits when they drafted the rule. ${ }^{38}$ The Note cites approvingly Empire Packing and other federal court of appeals decisions that adopted the state courts' majority rule; it explicitly rejects the approach of Campbell by citing it as "contra" the position of the rule. To these citations the committee added only that the cited cases support the "presumption of correctness which ought to attend" a conviction. Thus, with merely a nod to the concern that a conviction used to impeach be a reliable finding of guilt, the Note gives no more insight into the concerns engendered by the pendency of an appeal than we can glean from the reasoning of the majority-rule cases.

The difficulty with the majority-rule cases is that they do not provide an explanation that would persuade most people skeptical of rule 609 (e). Although the implication from the disapproving citation of Campbell is that Congress rejected the protective policy on which that decision was predicated, the majority cases simply do not respond to the Campbell court's concern with the problem of unfair prejudice from a subsequently reversed conviction. In deciding whether a conviction pending appeal constitutes a "conviction" for the purposes of impeachment statutes, the cases all begin by defining "conviction" as some stage-either a jury's verdict or a court's judgment-in the process of a criminal prosecution. Under either definition, a conviction pending appeal satisfies the statutory requirement, since the prosecution has reached the required stage. The weakness of these cases is their failure to explain why a pending appeal does not qualify the original definition of "conviction." An appeal may call into question the "presumption of correctness" that

35176 F.2d at 47.

${ }^{36}$ Id.

${ }^{77}$ E.g., State v. Blevins, 425 S.W.2d 155, 158-59 (Mo. 1968); State v. Blue, 129 N.J. Super. 8, 11-12, 322 A.2d 174, 176 (App. Div. 1974).

${ }^{35}$ Fed. R. Evw. 609(e), Advisory Comm. Note, 56 F.R.D. 183, 272 (1973); see text and notes at notes 18-21 supra. 
justifies rule 609(a)'s rule of admissibility, yet the explanations offered by the courts do not respond to the possibility that the appellate court might set aside the verdict for lack of sufficient evidence or errors that otherwise make the finding of guilt less reliable. ${ }^{39}$

The explanations offered by the majority-rule cases are generally narrow exercises in statutory interpretation that resolve the problem of a pending appeal without analyzing it. In the finaljudgment cases, ${ }^{40}$ the courts assumed that by stipulating "conviction" the legislature meant the concept of final judgment in its technical sense. Hence, they looked to rules formulated in other contexts to determine whether a conviction pending appeal is a final judgment. The jury-verdict cases similarly attach a technical definition to "conviction." judgment" or "jury verdict." They say only "conviction." ${ }^{2}$ Nothing in the language of the statutes suggests that the legislature intended any particular resolution to the question why a verdict or judgment that an appellate court might set aside nonetheless satisfies the definition of "conviction." Even those cases, such as Manning $v$. State ${ }^{43}$ in which the court has attempted to explain its decision with respect to the policy underlying the statutory exception for admission of a conviction as evidence have failed to go beyond the general rationale to face the specific problem of a pending appeal..$^{44}$

Although the various explanations offered by the majority-rule cases constitute an unpersuasive justification and an inadequate legislative history of rule 609(e), the general approach of the cases seems correct. The issue of a pending appeal is merely supplemental to the basic issue of admissibility of conviction evidence for the purpose of impeachment. The crucial question is thus whether a conviction pending appeal satisfies the policy underlying the admissibility of prior convictions as impeaching evidence.

\footnotetext{
See text and notes at notes 64-73 infra.

4. E.g., People v. Spears, 83 Ill. App. 2d 18, 226 N.E.2d 67 (1967); see text and note at note 32 supra.

"See, e.g., People v. Braun, 14 Cal. 2d 1, 92 P.2d 402 (1939); People v. Ward, 134 Cal. 301,66 P.372 (1901).

12 The language of the Texas statute is slightly different. It stipulates "final conviction." Texas Code Crim. Pro. Ann. art. 38.29 (Vernon 1966). The Texas courts have interpreted this to exclude any conviction pending appeal. See, e.g., Ringer v. State, 137 Tex. Crim. 242, 24647, 129 S.W.2d 654, 656 (1939).

t3 7 Okla. Crim. 367, 370, 123 P. 1029, 1030 (1912).

4 See text and notes at notes 25-26 supra.
} 


\section{Conviction as Conclusive Proof of a Witness's Prior Crime}

A. Admissibility of Evidence of Prior Crimes

1. Rule $608(b)$. Impeachment of a witness's credibility by means of prior crime evidence falls within the scope of rule 608(b), which permits a cross-examiner to inquire into "specific instances of conduct" of a witness "for the purpose of attacking or supporting his credibility," if the court finds such inquiry sufficiently probative of that issue. ${ }^{45}$ Rule 608 (b) allows questions about a witness's prior crimes, whether or not they have resulted in conviction, but prohibits introduction of any extrinsic evidence to prove that he committed the crime. If the witness denies having committed the crime and has not been convicted, the cross-examiner may do no more than press the witness for an admission. ${ }^{46}$

The reason for rule 608(b)'s general rule of exclusion is significant: it is to avoid having the trier of fact decide whether the witness engaged in particular conduct. The decision to exclude extrinsic evidence of specific conduct for impeachment purposes reflects the relative weights of the probative value of a witness's prior conduct on the one hand and the burden imposed on the judicial process by its presentation at trial on the other. ${ }^{47}$ Use of such evidence to impeach involves a two-step inference. Because the witness committed the act in question, the trier of fact attributes to him a certain character trait (untrustworthiness). From this trait the trier infers that the witness's testimony is suspect. Since neither of these inferences is compelling and since such evidence will generally be but one minor element of the body of proof presented at trial, the probative value of this evidence is particularly low.

On the other side of the balance, the problems introduced by adding the determination of the witness's conduct to the trial are

${ }^{15}$ FED. R. Evid. 608(b). The rule requires that the actions be "probative of truthfulness or untruthfulness." Id.

16 The cross-examiner may not attempt to rebut the denial with proof of the prior crime. United States v. Turquitt, 557 F.2d 464, 470-71 (5th Cir. 1977); United States v. Allende, 486 F.2d 1351, 1354 (9th Cir.), cert. denied, 416 U.S. 958 (1973); United States v. Yarbrough, 352 F.2d 491 (6th Cir. 1965); State v. Morgan, 541 S.W.2d 385 (Tenn. 1976). Nor may the crossexaminer rebut the witness's denial through the use of questioning that strongly suggests the witness's guilt. See Watkins v. Foster, 570 F.2d 501, 506 (4th Cir. 1978); People v. Alamo, 23 N.Y.2d 630, 636-37, 246 N.E.2d 496, 499, 298 N.Y.S.2d 681, 685 (Burke, J., dissenting), cert. denied, 396 U.S. 879 (1969); State v. Phillips, 240 N.C. 516, 527, 82 S.E.2d 762, 768 (1954); Brooks, The Treatment of Witnesses in the Proposed Rules of Evidence for the United States District Courts: Article IV, 25 Rec. A.B. CrTY N.Y. 632, 636-37 (1970). With respect to the court's broad discretion to prohibit this type of questioning, see 3 WeINSTEIN's EviDENCE, supra note 6, I 608[05], at 22-24.

4 See Hale, Specific Acts and Related Matters as Affecting Credibility, 1 Hastings L.J. 89 (1950). 
threefold ${ }^{48}$ First, to allow the parties to introduce evidence regarding a witness's conduct would significantly prolong the trial. In particular, relitigation of a prior finding of guilt would involve duplicative and wasteful use of judicial resources. Second, injection into the trial of a question distinct from that which must ultimately be decided could cause the jury to confuse the issues and proof raised in the course of the trial. Finally, the witness, or the party relying on his testimony, might not have anticipated that the other party would introduce evidence of specific actions as a means of impeachment. ${ }^{99}$ Because of the relatively low probative value of this type of evidence and the substantial potential for delay, confusion, and surprise entailed by its presentation, rule 608(b) avoids having the factfinder decide at trial whether the witness committed a crime raised to impeach.

2. Rule $609(a)$. Where a witness has been convicted of a crime, rule 609(a) provides an exception to rule 608(b) by allowing admission of the public record of the conviction that conclusively establishes the witness's commisson of the crime. ${ }^{50}$ Because rule 608(b) prohibits extrinsic evidence in support of a witness's credibility, thus apparently preventing the challenged witness from rebutting the conviction, the trier of fact faces positive proof on only one side of the issue. ${ }^{51}$ The only reasonable conclusion that the trier can reach, therefore, is that the witness committed the crime for which he was convicted. The precise role of a conviction is thus to allow

48 See Lee v. United States, 368 F.2d 834, 837 (D.C. Cir. 1966). See generally 3A J. WIGmore, supra note $1, \S 979$, at 826-27; Ladd, supra note 9, at 507-09.

" Surprise may result because the witness forgot the event, because he did not consider it a serious indication of untrustworthiness, or because the evidence of the action is false and misleading. The party relying on the witness might then be caught unprepared to challenge the foundation, competency, or strength of the evidence or to offer evidence of his own on the issue of the witness's past actions. His opponent could easily take advantage of his unpreparedness and score an unfair but successful attack on the credibility of the witness.

50 The exception accords with pre-rules federal-court practice, see United States v. Plante, 472 F.2d 829, 832 (1st Cir.), cert. denied, 411 U.S. 950 (1973), as well as with the practice in state courts, see Freeman v. Chicago Transit Authority, 33 Ill. 2d 103, 108, 210 N.E.2d 191, 194-95 (1965); Morrissey v. Powell, 304 Mass. 268, 272, 23 N.E.2d 411, 414 (1939) (dictum); Lamoureux v. New York, N.H.\&H.R.R., 169 Mass. 338, 340, 47 N.E. 1009, 1010 (1897) (Holmes, J.); Commonwealth v. Palarino, 168 Pa. Super. 152, 157, 77 A.2d 665, 667 (1951); State v. Harra, 22 Wash. 57, 60, 60 P. 58, 59 (1900).

si Some courts allow an impeached witness to give a brief explanation of the conviction for the purpose of denying guilt or mitigating the impact of proof of prior crime. United States v. Crisafi, 304 F.2d 803, 804 (2d Cir. 1962). But see Lamoureux v. New York N.H.\&H.R.R., 169 Mass. 338, 340, 47 N.E. 1009, 1010 (1897) (not error for trial court to prohibit witness's explanation of extenuating circumstances). McCormick explains that the reason for this practice is to "satisfy our feeling that some reasonable outlet for the instinct of self-defense by one attacked should be conceded, if it can be done without too much damage to the business at hand." HaNDBOOK, supra note $8, \S 43$, at 89 . 
proof when the witness denies committing the crime. A party may still challenge the suggested inferences of his witness's untrustworthiness, ${ }^{52}$ but the conviction settles the question of the witness's prior criminal acts.

By treating a conviction as conclusive proof of a witness's prior crime, rule 609(a) avoids the problems that underlie rule 608(b)'s rule of exclusion. ${ }^{53}$ The introduction of a witness's conviction to prove his prior crimes raises no likelihood of delaying the trial or confusing the issues. Furthermore, since a party may not challenge the finding of guilt in a conviction used to impeach one of his witnesses, that he might be unprepared to do so is of no significance. Thus, the conclusiveness of a conviction under rule 609(a) achieves two otherwise inconsistent objectives: the issue of the witness's prior crime is not litigated and evidence of the prior crime, which does have some probative value, is nonetheless available to impeach the witness at trial.

\section{B. The Justification for Conclusive Use of Convictions}

The conclusiveness accorded to a conviction as evidence of a witness's prior crime under rule 609(a) is not a necessary consequence of the verdict or judgment in the prior trial; ${ }^{54}$ rule $609(\mathrm{a})$ applies a prior conviction as conclusive proof of guilt in many cases in which collateral estoppel normally would not preclude relitigation of the prior crime.$^{55}$ Conclusiveness as a feature of proof by prior

52 Extrinsic proof admissible to rehabilitate the witness is limited to evidence of his character for truthfulness in the form of opinion or reputation. FED. R. Evid. 608(a).

ss See generally 3 A J. WIGMORE, supra note $1, \S 980$, at 828 . Surprise is not a factor, since both the witness and the party relying on his testimony may reasonably be presumed to know of any prior convictions.

st See generally 1B Moore's Federal Practice If 0.412[1] (2d ed. 1965).

35 For example, courts have traditionally applied a requirement of mutuality to collateral estoppel. Only a party or privy to a prior judgment could use it to preclude an issue in a subsequent case. With criminal convictions, this generally limited the benefit of collateral estoppel to the prosecuting government. See M.F.A. Mut. Ins. Co. v. Dixon, 243 F. Supp. 806, 813 (W.D. Ark. 1965); Silva v. Silva, 297 Mass. 217, 218, 7 N.E.2d 601, 601 (1937). Not even the earliest cases, however, restricted impeachment use of convictions to the prosecuting government. See, e.g., Hackett v. Freeman \& Graves, 103 Iowa 296, 298, 72 N.W. 528, 529 (1897); Lamoureux v. New York, N.H.\&H.R.R., 169 Mass. 338, 340, 47 N.E. 1009, 1010 (1897). A second example regards the parties barred by collateral estoppel. Since collateral estoppel does not bar an attack on a judgment by a litigant who was not a party or privy to the prior judgment, the doctrine would not bar a party from attacking a conviction used to impeach a coparty or nonparty witness. Artrip v. Califano, 569 F.2d 1298 (4th Cir. 1978); Defenders of Wildlife v. Andrus, 77 F.R.D. 448, 453 (D.D.C. 1978); Bernhard v. Bank of America Nat'l Trust \& Sav、 Ass'n, 19 Cal. 2d 807, 122 P.2d 892, 895 (1942). In spite of these discrepancies with respect to the doctrine of collateral estoppel, impeachment use of conviction evidence applies without regard to whether the party affected by the proof had any 
conviction appears to result not from an inherent characteristic of convictions, but rather from the utility of a conviction to prove a prior crime without the use of judicial resources required to put the witness's commission of the crime into issue..$^{5 B}$ Yet, the utility of making the conviction conclusive proof does not fully respond to the argument that this treatment of a conviction is unfair to the party relying either on his own testimony or that of a witness who is subjected to impeachment. If the trier of fact accepts that the witness committed the prior crime, this party could suffer an adverse judgment due either to the discrediting of important testimony or the development of jury prejudice. The party's right to a fair trial seems to demand that some justification be given for denying him an opportunity to challenge his opponent's proof on what could be a decisive issue.

The justification for precluding extrinsic rebuttal evidence cannot be the same as the explanation for precluding the relitigation of issues under collateral estoppel-that a party had a full opportunity to litigate the issues in the prior proceeding ${ }^{57}$ - since rule 609(a) applies as well to those situations in which the affected party had no opportunity to litigate the issue of his witness's guilt. Nor is it sufficient to argue that since the probative value of prior-crime impeachment evidence is so low, the party is unlikely to be harmed even if the impeaching conviction was incorrect. That prior-crime evidence is admissible indicates that it is believed to be relevant; hence it is possible that it will be outcome-determinative in a close case..$^{58} \mathrm{~A}$ party should not have to bear an adverse verdict without an opportunity to contest evidence that determined the outcome.

The only acceptable justification for the total preclusion of rebuttal evidence under rule 609 (a) is the reliability of the finding of guilt in the prior proceeding. Although a conviction can never be considered absolute proof of guilt, it is sufficiently reliable to make

opportunity to participate in the prior criminal trial. See, e.g., United States v. Rose, 526 F.2d 745 (8th Cir. 1975), cert. denied, 425 U.S. 905 (1976). See also note 73 infra.

s. See United States v. Plante, 472 F.2d 829, 832 (1st Cir.), cert. denied, 411 U.S. 950 (1973) (The "statement that the conviction is 'conclusive' . . . merely states the rule, not the reason.").

${ }^{77}$ See Blonder-Tongue Laboratories, Inc. v. University of Ill. Foundation, 402 U.S. 313, 328-29 (1971); Zenith Radio Corp. v. Hazeltine Research, Inc., 395 U.S. 100, 110-11 (1969).

s8 A verdict may depend on a jury's decision whether to believe a particular witness. See Brown v. Coating Specialists, Inc., 465 F.2d 340 (5th Cir. 1972) (plaintiff's only eyewitness was a convicted felon). The University of Chicago jury project found that in 25 percent of the cases they surveyed, the defense called just one witness. H. KaLven \& H. ZeISEL, supra note 8 , at 136. Although many of these cases do not involve witnesses whose testimony is singularly crucial to the defense, the large figure indicates that the cases in which it is crucial are probably not rare. 
this explanation valid. The primary element of reliability is the burden of proof: the conviction represents a jury's conclusion that evidence proves the witness's guilt beyond a reasonable doubt. ${ }^{59}$ Furthermore, the criminal trial contains numerous safeguards designed to ensure that the evidence actually satisfies this burden. If the trial proceeded in accordance with the rules of evidence and procedure and the requirements of the fifth and sixth amendments, then a subsequent court can reasonably assume that the finding of guilt was based on competent and sufficient evidence and that the accused had a fair opportunity to refute the charges against him. By requiring a conviction for the prior crime, rule 609(a) thus restricts the evidence of the crime to a form that has a high degree of certainty and that a party would be unlikely to refute if given the opportunity..$^{60}$

This explanation of the fairness of rule 609(a) implies that if convictions are to be admitted as impeaching evidence, reliability should be the basic criterion of the definition of "conviction" for the purposes of the rule. If a conviction does not represent a reliable determination of a witness's guilt beyond a reasonable doubt, then the possibility would not be remote that a party could successfully challenge an attempt to prove the prior crimes of his witnesses. In these circumstances, to allow evidence of the prior crimes but to prohibit any effective challenge to the evidence would be unjust to the adversely affected party. Since it is the policy of the Federal

32 Due process requires the prosecution to prove beyond a reasonable doubt every fact necessary to constitute the crime with which the accused is charged. In re Winship, 397 U.S. 358,364 (1970).

" Indeed, if the criminal trial properly found the witness guilty beyond a reasonable doubt, then the evidence of guilt would substantially exceed the burden that a party would have to meet if rule 608 (b) generally permitted extrinsic proof of a witness's prior crimes. Normally, when a litigant offers proof of prior criminal acts as circumstantial evidence of an alleged fact, the proof of the prior crime must satisfy a burden no greater than clear and convincing proof. See, e.g., United States v. Davis, 551 F.2d 233, 234-35 (8th Cir.), cert. denied, 431 U.S. 923 (1977); United States v. Ostrowsky, 501 F.2d 318, 321 (7th Cir. 1974); State v. Fetters, 202 N.W.2d 84 (Iowa 1972); Caruthers v. State, 219 Tenn. 21, 406 S.W.2d 159 (1966). In many jurisdictions, the burden is even lower. The Second Circuit requires only proof of the prior crime by preponderance of the evidence. United States v. Kahan, 572 F.2d 923, 932 (2d Cir.), cert. denied, 99 S. Ct. 112 (1978); United States v.'Leonard, 524 F.2d 1076, 1090-91 (2d Cir. 1975), cert. denied, 425 U.S. 958 (1976). See also People v. McClellan, 71 Cal. 2d 793, 804, 457 P.2d 871, 878, 80 Cal. Rptr. 31, 38 (1969). The Fifth Circuit has recently ruled that proof of prior crimes is admissible if it merely allows a reasonable inference that the witness committed the prior crime. United States v. Beechum, 582 F.2d 898, 909-13 (5th Cir. 1978) (en banc). See also MacEwen v. State, 194 Md. 492, 502, 71 A.2d 464, 468 (1950).

Thus, a valid conviction represents evidence that, if offered in the second trial to impeach the witness, would almost surely satisfy the requisite burden of proof. It is reasonable to conclude, therefore, that when a witness has been convicted, the chance that a party relying on his testimony could successfully challenge the proof of the prior crime is remote. 
Rules of Evidence to avoid litigating the issue of a witness's prior crime, the alternative in any case in which reliability is not assured is to exclude the prior crime evidence.

\section{The Problem of Impeachment with a Conviction Pending APPEAL}

The only reason consistent with the policy underlying rule 609(a) that an appeal might render a conviction inadmissible is the possibility of reversal after its use to impeach. ${ }^{81}$ Once a conviction has been reversed, it may not be used to impeach a witness. ${ }^{82}$ The common explanation of this rule is formal: the reversal removes the conviction from existence. As the Supreme Court of Washington recently explained, a conviction that has been reversed has been "voided and [stands] for naught." conviction is relevant, the pendency of an appeal raises no serious problems. There is no apparent inconsistency in saying that a person stands convicted before reversal but not after it.

In many cases, however, the appellate court will reverse for errors that reduce the reliability of the finding of guilt in the trial court. ${ }^{64}$ For example, the appellate court might rule that the evi-

"One group of cases holding convictions inadmissible during the pendency of an appeal, see, for example, Campbell v. United States, 176 F.2d 45 (D.C. Cir. 1949), based their holdings directly on the possibility of subsequent reversal. See text and notes at notes 33-37 supra. Even those state court decisions that arrived at a rule of exclusion by reasoning that a conviction is not technically a final judgment until exhaustion of an appeal indirectly resulted from the possibility of reversal. See Foure v. Commonwealth, $214 \mathrm{Ky} .620,628,283$ S.W. 958, 962 (1926).

12 United States v. Savage, 470 F.2d 948, 950 (3d Cir. 1972), cert. denied, 412 U.S. 980 (1973); Thomas v. United States, 121 F.2d 905, 907 (D.C. Cir. 1941); Card v. Foot, 57 Conn. 427, 432, 18 A. 713, 713 (1889); Hale v. United States, 361 A.2d 212, 215 (D.C. App. 1976); People v. Miller, 27 Ill. App. 3d 788, 791, 327 N.E.2d 253, 255 (1975), cert. denied, 424 U.S. 925 (1976); Kable v. State, 17 Md. App. 16, 299 A.2d 493, 501 (1973); State v. Blevins, 425 S.W.2d 155, 158 (Mo. 1968); Poore v. State, 524 S.W.2d 294, 296 (Tex. Crim. App. 1975). But see Manning v. State, 7 Okla. Crim. 367, 370, 123 P. 1029, 1030 (1912).

is State v. Hill, 83 Wash. 2d 548, 561, 520 P.2d 618, 619-20 (1974). Compare the effect of releasing a prisoner on a habeas corpus petition upon the status of his conviction. The Third Circuit has held that release on habeas "does not have the force and effect of voiding a conviction" and hence does not automatically render the conviction inadmissible for purposes of impeachment. Smith v. Spina, 477 F.2d 1140, 1147 (3d Cir. 1973). Rather, the court viewed release on habeas corpus as equivalent to a pardon or annulment, which renders the conviction inadmissible only if it is "based on a finding of innocence." Id. at 1147; accord, State v. Kiser, 111 Ariz. 316, 317-18, 529 P.2d 215, 216-17 (1974). See FED. R. Evid. 609(c). But see People v. Shook, 35 Ill. 2d 597, 600, 221 N.E.2d 290, 292 (1966) ("discharge by habeas corpus refers to the actual conviction and declares it to be void").

" Because a conviction is nevertheless inadmissible after reversal for formal reasons, no court has yet considered the effect of a reversal in reducing reliability. On a related issue, courts have considered the effect of various constitutional errors on the reliability of a convic- 
dence produced at trial was insufficient to support the verdict, finding that no reasonable juror could find guilt beyond a reasonable doubt. ${ }^{65}$ The court might also reverse for various errors that reduce to a lesser degree the reliability of the finding of guilt in the prior proceeding. ${ }^{66}$ These errors include admission of hearsay or prejudicial evidence, improper exclusion of evidence offered by the accused, and violations of procedural requirements, such as adequate counsel for the accused, that protect the defendant's ability to mount an effective defense. Some grounds for reversal, however, raise no doubts about the correctness of the finding of guilt. The clearest example is reversal due to admission of evidence obtained in violation of the fourth amendment. The purpose of reversal in fourth amendment cases is not to ensure a correct verdict but to discourage police violation of the rules on search and seizure. ${ }^{67}$ With the exception of cases involving issues like the fourth amendment, ${ }^{68}$ though, a reversal of a conviction constitutes a determination that the prior proceeding did not find guilt with a sufficient degree of certainty.

The possibility that any conviction introduced during the pendency of an appeal will eventually prove unreliable is small, but not insignificant. In the United States courts of appeals, the rate of reversal of criminal convictions that are appealed is somewhat greater than ten percent. ${ }^{69}$ Reversals by the appellate courts of most states occur at similar rates. ${ }^{70}$ Some of these reversals, of course, are for fourth amendment violations and other errors that do not reduce reliability. Statistics on these reversals are not available, but a con-

tion when the issue is whether impeachment of a criminal defendant with a constitutionally defective prior conviction constitutes reversible error. Compare United States v. Penta, 475 F.2d 92 (1st Cir.), cert. denied, 414 U.S. 870 (1973), with Gilday v. Scafati, 428 F.2d 1027 (1st Cir.), cert. denied, 400 U.S. 926 (1970).

is See United States v. Stirling, 571 F.2d 708, 726 (2d Cir.), cert. denied, 99 S. Ct. 93 (1978).

" But even here a reversal indicates that the error reduced the reliability of the conviction below the "beyond a reasonable doubt" threshold. If it had not, it would have been dismissed as "harmless error" and the conviction would not have been reversed. Krulewitch v. United States, 336 U.S. 440, 444-45 (1949).

17 Stone v. Powell, 428 U.S. 465, 482-89 (1976); see United States v. Penta, 475 F.2d 92, 94 (1st Cir.), cert. denied, 414 U.S. 870 (1973); State v. Murray, 86 Wash. 2d 165, 168, 543 P.2d 332, 334 (1975).

is Other examples of grounds for reversal that do not question the correctness of the finding of guilt are prosecutions in violation of the double jeopardy clause and admission of evidence that violates a privileged communication. See Benton v. Maryland, 395 U.S. 784, 793-97 (1969) (double jeopardy); 8 J. WigMore, EvideNCE § 2285 (J. McNaughton rev. 1961) (privileged communications).

" [1978] Admin. Office of the U.S. Courts Ann. Rep A-3 to A-5.

70 See, e.g., [1976] Admin. Office of the ILL. Courts ANN. REp. 97 (approximately 10 percent reversed by appellate courts); [1978] Admin. Court of the Cal. Courts ANn. Rep. 72 (approximately 8 percent reversed by appellate and supreme courts). 
servative estimate would be that of the convictions used to impeach while an appeal is pending, some number between five and ten percent will ultimately be reversed for errors that reduce reliability.

Reversals on grounds of unreliability do not establish the innocence of the person convicted in the lower court. Most likely, substantial evidence of guilt will remain. ${ }^{71}$ The problem with permitting impeachment with a conviction that has been, or will be, reversed on grounds of unreliability is that the reversal removes the basis for justifying the treatment of the conviction as conclusive proof of the prior crime. If the evidence produced at the first trial does not prove guilt beyond a reasonable doubt or if the convicted person did not have the benefit of normal procedural and evidentiary safeguards, then the conviction does not represent proof of guilt of the same high degree of certainty as a conviction free of these defects. To be sure, the deficiency might be trivial and the likelihood remote that a litigant who would wish to challenge the proof of his witness's prior crimes could do so successfully. But the deficiency could be substantial, and the evidence produced at the prior trial could be insufficient to foreclose effectively the possibility that a litigant could successfully challenge an attempt to prove his witness's prior crimes. In these latter cases, there is a significant element of unfairness in using the conviction to establish conclusively against a litigant the fact of a prior crime of his witness. ${ }^{72}$ Convictions reversed

"The reversals at issue here are ones that did not result in a second conviction or remand of the case. If the unreliable conviction is merely replaced with a reliable one, use of the first conviction as proof of guilt should cause no problems. See United States v. Cipullo, 170 F.2d 311, 313 (2d Cir. 1948), cert. denied, 336 U.S. 946 (1949).

72 The unfairness considered here is similar to the due process violation found in Loper v. Beto, 405 U.S. 473 (1972). The trial court had allowed impeachment of a criminal defendant with a prior convicton for which the defendant had not been provided assistance of counsel, but which had never been set aside or revoked. The Supreme Court concluded that since the use of the conviction to impeach could have affected the outcome of the trial, the trial court erred in permitting it. 405 U.S. at 480, 483-84. The basis of the Court's reasoning in Loper was the lack of reliability of a conviction obtained without the aid of counsel. Since a criminal defendant has a right, guaranteed by due process, to certain procedures which serve to ensure that the jury's finding of guilt will be based on a fair trial, the defendant ought not be deprived of this right indirectly by the establishment of facts against him with the findings of a prior trial in which he was denied the benefits of these procedures. The due process right announced in Loper overlaps the concept of fairness under rule 609(a). Once a conviction has been reversed on the ground of failure to provide the accused with counsel or of denial of another constitutional right tied to reliability, use of the conviction in a subsequent trial to impeach a criminal defendant would violate both the due process right announced in Loper and the limitation on convictions admissible and under rule 609(a) discussed here.

The two concepts are not equivalent, however. In one respect, the Loper rule applies more broadly. As in Loper itself, the constitutional error need not have resulted in reversal of the conviction. Rather, the court considering admissibility of the conviction to impeach must 
on grounds of unreliability, therefore, do not constitute a class of cases that meet the threshold of reliability required for use under rule $609(\mathrm{a})$.

In summary, the problem caused by impeachment with a conviction during the pendency of an appeal results from the inevitable reversal of some of the convictions for errors that reduce the reliability of the finding of guilt. When such a reversal occurs after the use of the conviction to obtain a judgment in a second trial, the party who suffers the impeachment of his or his witness's testimony can reasonably argue that the admission of the conviction as conclusive proof was unfair and that the judgment against him is unjust. ${ }^{73}$ The question that remains is how best to protect or vindicate the interest of this aggrieved party.

\section{Resolving the Problem of Subsequent Reversal}

Rule 609(e) reflects Congress's judgment that the evidentiary value of a conviction pending appeal outweighs the apparent unfairness to a party who suffers an adverse judgment due to impeachment with a conviction subsequently reversed on grounds of unreliability. ${ }^{74}$ The obvious interest served in admitting the convictions is

inspect the record of the prior proceeding to determine whether even unappealed constitutional errors occurred. See 3 Weinstern's Evidence, supra note 6, If 609[07], at 93. In most respects, though, the reliability limitation of rule 609(a) applies more broadly. First, Loper was an exercise in constitutional rulemaking and might only apply to constitutional errors in the prior proceeding. The reliability requirement of a conviction under rule $609(\mathrm{a})$, on the other hand, is an interpretation of the rule. No reason exists to limit its application to convictions that are unreliable due to constitutional error. Second, Loper concerns the due process rights of criminal defendants whereas the interpretation of rule 609(a) concerns fairness to any litigant adversely affected by impeachment with evidence of conviction. Thus, the similarity between the two notions begins and ends with the general notion that a conviction used to impeach should satisfy a high threshold of reliability. Cf. Glick, supra note 16, at 347-49 (suggesting that the rule eventually announced in Loper be incorporated into rule 609(e)).

7s The effect would be the same if consideration were limited to cases in which the person convicted is himself the impeached witness and affected party in the subsequent trial and if the justification for conclusiveness were the application of collateral estoppel. See notes $\mathbf{5 5}$ \& 57 supra. When an appellate court reverses on geounds of insufficient evidence or trial error, which reduce the reliability of the finding of guilt, the claim that the affected party had a full and fair opportunity to litigate the issues in the prior proceeding has no merit. See Blonder-Tongue Laboratories, Inc. v. University of Ill. Foundation, 402 U.S. 313, 329 (1971). Cf. Parklane Hosiery Co. v. Shore, 99 S. Ct. 645, 651 (1979) (A court may use its discretion to deny collateral estoppel "where the second action affords the defendant procedural opportunities unavailable in the first action that could readily cause a different result.") (footnote omitted).

74 Recall that the advisory note explicitly rejected the holding of Campbell v. United States, 176 F.2d 45 (D.C. Cir. 1949), which reasoned that the possibility of subsequent reversal compelled a rule of exclusion. FED. R. Evid. 609(e), Advisory Comm. Note, 56 F.R.D. 183, 272 (1973). See text and notes at notes 34-36, 38 supra. 
the benefit of evidence relevant to the issue of a witness's credibility ${ }^{75}$ Two considerations enhance the interest in admitting convictions pending appeal. First, Congress adopted a form of rule 609(a) that is substantially less restrictive than others urged upon it and thus expresses a generally favorable attitude toward admission of this evidence. ${ }^{78}$ Second, convictions pending appeal will generally be more probative of credibility than unappealed convictions, since in most cases they will prove recent crimes. ${ }^{77}$

Recognizing the value of admitting the evidence, however, does not correct the unfairness of impeachment with unreliable convictions when it occurs. ${ }^{78}$ The explanation for rule 609(e) may be that this cost to some defendants must be tolerated in order to derive the benefits of conviction evidence. But the explanation might also be that means other than a general rule of exclusion are available to resolve the problem. There are at least three possible solutions: informing the jury of the pendency of an appeal, excluding the evidence under rule 609(a)(1), and granting a new trial when a conviction is reversed. Any of these, if it substantially compensates for the risk of unfairness, might justify Congress's decision to eschew a blanket rule against admitting convictions pending appeal for impeachment purposes. ${ }^{79}$

$7 s$ See text and note at note 12 supra.

76 See H.R. REP. No. 650, 93rd Cong., 1st Sess. 11 (1973); S. REp. No. 1277, 93rd Cong., 2d Sess. 14 (1974). See also United States v. Smith, 551 F.2d 348, 358 \& n.20, 359 (D.C. Cir. 1976).

$\pi$ See United States v. Soles, 482 F.2d 105, 108 (2d Cir.), cert. denied, 414 U.S. 1027 (1973) (Friendly, J.).

"s Some courts have refused to set aside a judgment obtained with the aid of a conviction pending appeal, even though the conviction has since been reversed. Since the witness did stand convicted at the time of the impeachment, they reason, no relief is necessary when reversal actually occurs. Bloch v. United States, 238 F.2d 631 (9th Cir. 1956), cert. denied, 353 U.S. 959 (1957); Latikos v. State, 17 Ala. App. 655, 656, 88 So. 47, 48 (1921); People v. Braun, 14 Cal. 2d 1, 6, 92 P.2d 402, 405 (1939); People v. Miller, 27 IIl. App. 3d 788, 791-92, 327 N.E.2d 253, 256 (1975), cert. denied, 424 U.S. 925 (1976); Nicholson v. State, 254 So. $2 \mathrm{~d}$ 881, 883-84 (Miss. 1971); State v. Crawford, 60 Utah 6, 12-13, 206 P. 717, 719-20 (1922). But see United States v. Soles, 482 F.2d 105, 107-08 (2d Cir.), cert. denied, 414 U.S. 1027 (1973); State v. Kiser, 111 Ariz. 316, 317, 529 P.2d 215, 216 (1974). This reasoning might apply to the effect of a reversal in removing the formal status of conviction but it is inapplicable to the effect of finding a conviction inadequately reliable. If an appellate court finds that the witness's conviction was based on insufficient evidence or that trial errors in the prior proceeding reduced its reliability, it has found a defect that reaches reliability before as well as after the appellate court decision.

"An additional argument against a blanket rule is that it might encourage parties wishing to avoid impeachment in subsequent trials to file frivolous appeals. Judge Friendly, for one, has noted this possibility. United States v. Soles, 482 F.2d 105, 108 (2d Cir.), cert. denied, 414 U.S. 1027 (1973). 


\section{A. Informing the Jury of the Pendency of the Appeal}

The first solution derives from rule 609(e) itself. The rule provides that "[e]vidence of the pendency of an appeal is admissible." ${ }^{80}$ Several states also specifically permit informing the jury of a pending appeal. ${ }^{81}$ When Congress earlier enacted a comparable provision in the District of Columbia Code, it expressed the belief that the jury's knowledge of a pending appeal eliminates "any potential question of reversal in the event the conviction used as impeachment is reversed on appeal." 82 The jury's knowledge of the appeal cannot reasonably be expected to have this corrective effect, however. Before a jury member can make use of the evidence, either to judge a witness's credibility or to develop a bias against a party, he must decide whether the witness committed the crime for which he was convicted. The totality of the evidence on which he must base this decision is the conviction and the appeal. The appeal represents a finite, but small probability that the jury or court in the prior criminal proceeding erred. ${ }^{83}$ Unless the jury member has a grandly exaggerated conception of the possibility of reversal or of erroneous conviction, ${ }^{84}$ his only reasonable conclusion is that the witness committed the crime, and the juror will draw inferences based on this conclusion.

The jury's knowledge of the appeal, if rationally applied, will thus have no effect on its use of conviction evidence. The most that can be said for informing the jury of the appeal is that it cautions the members to draw inferences of dishonesty from the prior crime with some degree of skepticism. So long as the evidence of conviction can influence the outcome of a trial, however-and presumably it would not be admissible unless it could-the possibility remains that a party may suffer an adverse judgment due to impeachment of his witnesses or himself with a conviction that is subsequently reversed. ${ }^{85}$

so FED. R. Evid. 609(e). The Fifth Circuit recognized this privilege just prior to the adoption of the Federal Rules of Evidence: "[T]he defense may show that which is also a fact-the conviction is on appeal and, as any average juror would know, may be set aside." United States v. Franicevich, 471 F.2d 427, 429 (5th Cir. 1973).

s1 People v. Bey, 42 Ill. 2d 139, 146, 246 N.E.2d 287, 291 (1969); State v. Waller, 11 N.C. App. 434, 435, 181 S.E.2d 195, 196 (1971). See also D.C. CoDE § 14-305(d) (Supp. V 1972).

82 H.R. REP. No. 907, 91st Cong., 2d Sess. 164 (1970) The Advisory Note to the federal rule says only: "The pendency of an appeal is, however, a qualifying circumstance properly considerable." FED. R. Evid. 609(e), Advisory Comm. Note, 56 F.R.D. 183, 272 (1973). See text and notes at notes 69-72 supra.

st One critic of rule 609(e) suggests that the laymen of the jury probably view an appeal "as a technical device having little relation to guilt or innocence." Glick, supra note 16, at 347.

ss Although jurors may often be wrong in their evaluation of circumstantial evidence, use 
B. Exclusion Under Rule 609(a)(1)

A second solution to the problem of subsequent reversal is for the trial court to exclude evidence of conviction whenever rule 609(a) would permit exclusion. In the case of impeachment with conviction for crimes not involving dishonesty or false statement, the trial court may exclude a conviction when the risk of prejudice to the defendant outweighs probative value. ${ }^{88}$ Whenever an appeal raises the possibility of reversal on grounds of unreliability, it increases the possibility that the conviction is erroneous and that the witness did not commit the crime that is offered to prove his dishonesty. As this latter possibility increases, the overall probative value of the conviction as circumstantial proof of the witness's sincerity declines. In some cases the effect of this decline in probative value may be to tip the balance between prejudice and probative value against admissibility. Hence, the problem of subsequent reversals might be avoided altogether by exclusion of the evidence. ${ }^{87}$

The problem with this suggestion is that the trial court's balancing would allow it to exclude only a fraction of the convictions that are appealed on reliability grounds. First, rule 609(a) does not authorize the trial court to balance prejudice and probative value for crimes involving dishonesty or false statement..$^{88}$ Second, even when the trial court has discretion to exclude convictions, it could not reasonably find that an appeal raising issues of reliability greatly reduces the probative value of the conviction evidence. As noted, only about ten percent of appeals result in reversal, ${ }^{89}$ and a reversal establishes only that the prosecution did not prove guilt fairly and beyond a reasonable doubt. Only a fraction of these reversals represent actually erroneous convictions. An appeal, therefore, would only marginally increase the probability of erroneous conviction. It would have the effect of rendering a conviction inadmissible only when probative value and prejudice are otherwise closely in balance.

When cases arise in which the trial court does have discretion to exclude a conviction, the judge should examine the record of the

of convictions as circumstantial evidence is distinguishable because the party does not normally have an opportunity to offer evidence to challenge the reliability of the conviction.

FED. R. Evid. 609(a)(1).

87 Although rule 609 (e) does state that an appeal "does not render evidence of a conviction inadmissible," the rule can be read as only rejecting a blanket rule excluding all convictions pending appeal, not as precluding use of pendency as a factor in making individual decisions to exclude under rule 609(a)(1).

s FED. R. Evip. 609(a)(2).

see text and notes at notes 69-70 supra. 
first trial. He may conclude that there is a reasonable chance for reversal on reliability grounds. Since the evidence in these cases is already on the borderline of admissibility, the interest in admitting it is not especially strong. If the courts are sensitive to the problems that attend the reversal of a conviction used to impeach, they should use their discretion to exclude the conviction.

\section{New Trial}

The third solution to the problem of subsequent reversals is to grant a new trial. The unfairness presented in the case of a subsequent reversal is the adverse judgment in the second trial: an appellate court has determined that the prior conviction is insufficiently reliable to use to impeach a witness, but the second judgment, obtained with the use of the now overturned prior conviction, remains. The new-trial remedy deals with this problem by setting aside the second judgment.

In order to respond satisfactorily to the problem of subsequent reversal, the new-trial remedy need not be automatic. If the conviction did not influence the outcome of the trial in which it was used to impeach-which will be true in the majority of cases-then no claim of unfairness can arise. Impeachment of a party's witness, or of a party himself, can lead to an adverse judgment in one of two ways: the impeachment may successfully discredit testimony necessary for the party's case,$^{90}$ or it may cause the jury to develop a bias against the party. ${ }^{91}$ The task of determining whether use of a conviction influenced the outcome of a trial is much like applying the

* Typically, the discrediting effect will not be a critical aspect of the trial. The jury may well give greater weight to other means of impeachment, such as contradictions or suspicious demeanor elicited on cross-examination. Moreover, the outcome of a trial will seldom rest alone, or in large part, on the jury's belief of one witness. The case is not inconceivable, however, in which the jury's verdict depends on its willingness to believe one witness. For example, in a trial to determine fault for an automobile accident, a party may have a single eye-witness to support his allegations. He will lose the case if his opponent persuades the jury to disbelieve his witness on the basis of a prior conviction.

"As noted, this is primarily, although not exclusively, a problem that arises with the impeachment of criminal defendants. See note 8 supra. The University of Chicago jury project, H. Kalven \& H. Zeisel, supra note 8, demonstrated a serious danger that the jury will use the conviction to judge not only the defendant's credibility but his guilt as well. Id. at 159-60. The project also demonstrated that defendants often forgo testifying in their own behalf in order to avoid subjecting themselves to impeachment with a possibly prejudicial conviction. Id. at 146. Failure to take the stand could be harmful to a defendant whose case could be greatly enhanced with the addition of his own testimony. See United States v. Smith, 551 F.2d 348, 357 (D.C. Cir. 1976); United States v. Paige, 464 F. Supp. 99, 101 (E.D. $\mathrm{Pa}$. 1978) (defendant's "defense will be prejudiced severely if he is deterred from testifying from fear that he will be convicted on the basis of a prior crime") (citing Suggs v. United States, 391 F.2d 971 (D.C. Cir. 1968)). 
harmless-error test to trial errors. ${ }^{22}$ A court could conclude that a subsequently reversed conviction did not have prejudicial effects by viewing the trial record for evidence that other means of impeachment substantially discredited the witness's testimony or that no significant possibility of jury prejudice existed. The consequence of limiting the new trial remedy in this manner is to restrict its use to setting aside only those judgments that are subject to an actual claim of unfairness based on impeachment with unreliable convictions.

This solution has one obvious drawback: it requires a new trial. A second trial can be expensive and emotionally taxing for the litigants, and it requires the expenditure of additional judicial resources. In some cases, a trial court can prevent these burdens by staying its proceedings until completion of an appeal on the conviction of a witness. ${ }^{93}$ For those cases in which a stay would not prevent the need for a new trial, the burden of relitigation does not appear to be an adequate reason for denying relief altogether. The party who suffers impeachment and loses a trial as a result would certainly prefer the option to relitigate the case. The burden cannot be too great for the prevailing party, since courts regularly set aside judgments for closely analogous defects, as when unreliable hearsay evidence has been admitted..$^{94}$ Finally, the burden on the judicial system would not be great since a new trial would be required in only a small percentage of cases..$^{95}$

As a solution to the problem of subsequent reversals, the new trial remedy is preferable to a rule excluding convictions pending appeal from use as impeachment evidence. The new trial remedy

32 See Lutwak v. United States, 344 U.S. 604, 618-20 (1953); Campbell v. United States, 176 F.2d 45, 47-48 (D.C. Cir. 1949). See generally Kotteakos v. United States, 328 U.S. 750, 763-65 (1946). In civil trials, a court will generally hold harmless any erroneous admission of evidence when the evidence does not appear to have substantially contributed to the outcome of the trial. Lenz v. Southern Pacific Co., 493 F.2d 471, 472 (5th Cir. 1974); Hoffman v. Sterling Drug, Inc., 485 F.2d 132, 140 (3d Cir. 1973).

${ }^{23}$ A trial court has wide discretion to stay its proceeding, pending the outcome of a separate proceeding, in the interest of the economy of the time and effort of both the court and the parties. Landis v. North Am. Co., 299 U.S. 248, 254-56 (1936); CMAX, Inc. v. Hall, 300 F.2d 265 (9th Cir. 1972); Uniroyal, Inc. v. Sperberg, 63 F.R.D. 55, 60 (S.D.N.Y. 1973). When the admission of a witness's conviction could have a significant effect in determining the outcome of a trial, and when awaiting the outcome of an appeal of a conviction would not unfairly burden the parties, the trial court would have sufficient reason to issue a stay and thus avoid any need for a second trial should the appeal result in a reversal. One problem with this approach, as with a blanket rule of exclusion, is that it encourages parties to make frivolous appeals in order to delay, perhaps indefinitely, their subsequent trials.

" See, e.g., Pittsburgh Press Club v. United States, 579 F.2d 751 (3d Cir. 1978); United States v. Ragano, 476 F.2d 410 (5th Cir. 1973).

os See text and notes at notes 69-70 supra. 
would serve the interest of admitting this evidence, which the draftsmen of rule 609 deemed relevant; $;^{96}$ the only advantage to a rule of exclusion is the avoidance of the costs of new trials. Since the new-trial remedy would not require a substantial number of new trials, ${ }^{97}$ it seems preferable.

Whether the advantages of the new-trial remedy can serve as a rationale for rule 609(e) depends upon the extent of its availability. Although only one panel of the Second Circuit ${ }^{98}$ and the Supreme Court of Arizona ${ }^{99}$ have recognized a right to a new trial in cases in which a conviction used to impeach has subsequently been reversed, ${ }^{100}$ a federal court's authority to grant a new trial seems broad enough to cover those cases in which it is possible to make postverdict motions to the trial court. A federal court may, in criminal cases, grant a new trial whenever it is "in the interest of justice"101 to do so. A court's discretion to remedy injustice should reasonably extend to a claim of a party who was unable to challenge critical evidence that is later proven unreliable. In civil cases, the Federal Rules of Civil Procedure allow new trials for any of the reasons for which new trials have traditionally been granted. ${ }^{102}$ Although the specific case of reversal of a conviction used to impeach is without precedent in the federal courts, it is closely analogous to cases in which new trials are regularly granted. ${ }^{103}$ Since trial courts may grant new trials in cases involving unreliable evidence and reversal of judgments used as conclusive proof at trial, they should also have that authority in the case of reversal of a conviction used to impeach. Thus, in any case-criminal or civil-in which reversal occurs in time for a party to file a post-verdict motion, the trial court would have authority to grant a new trial.

The grounds for granting a new trial based upon a post-verdict motion do not apply in every case in which relief might be war-

96 See text and notes at notes 75-77 supra.

${ }^{27}$ See text and note at note 70 supra.

98 United States v. Soles, 482 F.2d 105, $107-08$ (2d Cir.), cert. denied, 414 U.S. 1027 (1973).

20 State v. Kiser, 111 Ariz. 316, 529 P.2d 215, 216 (1974).

100 Several courts have rejected the right to a new trial on the reasoning that since the witness stood convicted at the time he was impeached, the reversal presents no problems that requires a remedy. See note 78 supra.

101 Fed. R. CRIM. P. 33.

102 FEd. R. Civ. P. 59(a).

${ }^{105}$ A court may grant a new trial if it previously allowed highly unreliable hearsay evidence to reach the jury. See United States v. Campanaro, 63 F. Supp. 811, 815 (E.D. Pa. 1945). Grounds for new trial also exist when a prior judgment that precluded relitigation of issues at trial has since been reversed. Butler v. Eaton, 141 U.S. 240 (1891). 
ranted. ${ }^{104}$ The rules of procedure impose strict time limits on postverdict motions: such motions must be made within seven days of the jury's verdict in criminal cases ${ }^{105}$ and within ten days of entry of judgment in civil cases. ${ }^{108}$ The grounds for granting a new trial -after expiration of these periods are more restrictive.

Of the recognized grounds for granting new trials after expiration of the time for post-trial motions, the one most likely to support a new trial in the reversal cases is newly discovered evidence. ${ }^{107}$ The reversal of a prior conviction is not new evidence in the sense that it is evidence a jury would consider in a second trial. It is, however, new evidence that a judge would consider in his ruling on the admissibility of a witness's conviction. ${ }^{108}$ The reversal may establish that the conviction is not a sufficiently reliable finding of guilt to satisfy the requirements of rule 609 (a).$^{109}$

Two restrictions on the newly discovered evidence motion limit its availability. First, a party must file the motion within two years in criminal trials, ${ }^{110}$ and within one year in civil trials. ${ }^{111}$ Although these time periods are substantial, the appellate process is not so speedy that reversals will always occur within the time permitted to file a motion for a new trial. ${ }^{112}$ Second, the moving party must show that in a new trial, the exclusion of a witness's conviction

104 The new trial remedy might also be unavailable due to an exercise of the court's discretion to deny a motion for a new trial when it would not be "in the interests of justice." Frd. R. Crim. P. 33. See 7 Moore's Fedbral Practice \60.19 (2d ed. 1971) (civil trials); 2 C. Wright, Federal Practice \& Procedure $\$ \S 551,556$ (1969) (criminal trials). The court might find that the burden of a new trial in a particular case would be unusually great and that this consideration outweighs the unfairness of the impeachment.

105 FED. R. CRIM. P. 33.

10 Fed. R. Civ. P. 59(a).

in See FEd. R. Crv. P. 60(b)(2); Fed. R. CRnM. P. 33. In United States v. Soles, Judge Friendly suggested that the reversal of a conviction used to impeach a criminal defendant would constitute newly discovered evidence. 482 F.2d 105, 107 (2d Cir.), cert. denied, 414 U.S. 1027 (1973).

${ }^{105}$ The motion would be similar to a motion based on the recanting of testimony by one witness. At least in criminal cases the court may order a new trial if it finds, by some degree of probability, that the jury would have acquitted the defendant if the recanted testimony had not been heard. United States v. Wallace, 528 F.2d 863, 866 (4th Cir. 1976); United States v. Meyers, 484 F.2d 113, 116-17 (3d Cir. 1973). The courts disagree on what degree of probability must be shown. See note 113 infra.

${ }^{105}$ See text and notes at notes 64-68 supra.

110 FEd. R. Crim. P. 33.

111 Fed. R. Crv. P. 60(b)(2).

112 During 1976, the Illinois courts of appeals decided 44 percent of criminal appeals within one year of filing and 94 percent within two years of filing. [1976] AdMIN. OfFice of THE Ill. CourTs. ANN. ReP. 98. For criminal appeals in the New Jersey Superior Court, Appellate Division, the median lapse of time from the entry of a trial court judgment to an appellate court decision was between seventeen and eighteen months. [1976-1977] ADMIN. DrR. Of THE N.J. CourTs ANN. REP. tables 1 \& 1A, at B-27 to B-32. 
would probably lead to an acquittal in a criminal case ${ }^{113}$ or to a different result in a civil case. ${ }^{114}$ This burden would not block a new trial in those cases in which the reversal of a conviction used to impeach leaves standing those judgments that seem most unfaircases in which the losing party would probably have prevailed had not a conviction, now reversed, been used to impeach his or his witness's testimony.

In less clear-cut cases some unfairness would remain, however. A litigant may be able to prove that he probably lost a prior trial because his opponent successfully discredited an important witness with a prior conviction. Upon reversal of that conviction, he may be unable to obtain a new trial because he is unable to prove the further point that the jury would have believed his witness's testimony. Moreover, a convicted person may show that he failed to testify at his own trial because he feared the prejudicial effect of a prior conviction since reversed. In order to obtain a new trial after the reversal of the prior conviction, he must also prove that a jury would believe his testimony and would acquit him after hearing it. Thus, the newly discovered evidence motion offers only a partial remedy to the problem of subsequent reversal. ${ }^{115}$

Nonetheless, the new-trial remedy appears to be available in a substantial number of cases in which a subsequent reversal might give rise to a claim of unfairness. To the extent that it is available, there is no compelling reason for not permitting impeachment with a conviction pending appeal. If a large number of cases warranting relief are beyond the reach of the currently recognized grounds for a new trial, an extension of these grounds would be preferable to a general rule of exclusion. The present and potential availability of the new trial remedy provides a reasonable justification for rule 609 (e)'s rule of admissibility.

$1132 \mathrm{C}$. WRIGHT, supra note $104, \$ 557$. In the case of recanted testimony, the traditional rule required a demonstration only that the jury might have acquitted without the testimony. Larrison v. United States, 24 F.2d 82, 87 (7th Cir. 1928). Recently some courts have abandoned this rule and have required a showing of probable acquittal. See United States v. Stoksky, 527 F.2d 237, 245-46 (2d Cir. 1975), cert. denied, 429 U.S. 819 (1976). Other courts continue to follow the traditional rule. See United States v. Wallace, 528 F.2d 863, 866 (4th Cir. 1976).

i14 7 Moore's Federal Practice $\{60.23[4]$, at 275 (2d ed. 1971).

115 In an unusually serious case of unfairness, a court might consider a general collateral attack on the prior judgment. In criminal cases resulting in imprisonment, the proper form of attack would be a motion in the nature of habeas corpus. A collateral attack may be grounded on nonconstitutional defects in exceptional circumstances. See Davis v. United States, 417 U.S. 333 (1974). In civil cases, the court has the authority to set aside any prior judgment, notwithstanding the absence of any recognized ground for a new trial, if it finds "any other reason justifying relief from the operation of the judgment." FED. R. Crv. P. $60(b)(6)$. 


\section{Conclusion}

Rule 609(e) permits impeachment of a witness with a conviction pending appeal, thus creating the possibility that a witness's testimony may be discredited by a conviction subsequently reversed on appeal. This possibility is troubling because the conviction is treated as conclusive proof that the witness committed a particular crime: its introduction allows the jury to draw inferences of untrustworthiness from the fact of the crime. Evidence of a conviction may also introduce a danger of jury prejudice to the defendant. Because the proof of the prior crime may, in some cases, have decisive consequences on the outcome of a trial and because the conviction constitutes conclusive proof, its use to impeach can only be justified on the basis of the reliability of the finding of guilt underlying the conviction. A reversal of the conviction undercuts this justification because the grounds for reversal may be some defect that significantly reduces the reliability of the finding of guilt. Although the legislative history of rule 609 does not clearly reveal the actual intentions of the draftsmen, the rationale that can be derived from a reconsideration of the reasons for the rule suggests that, in at least some cases of subsequent reversal, a new trial should be available. Granting a new trial in appropriate cases, while remaining consistent with the legislative decision to allow impeachment with convictions pending appeal, adequately resolves the problems associated with such a practice. 